\title{
Analisa Rekayasa Ulang Proses Bisnis Pada UD. Top Stiker
}

\author{
Dewi Aprilitasari ${ }^{* 1}$, llyas Nuryasin ${ }^{2}$, Vinna Rahmayanti ${ }^{3}$ \\ $1,2,3$ Universitas Muhammadiyah Malang \\ e-mail: 20151037031206@webmail.umm.ac.id ${ }^{1}$, ilyas@umm.ac.id², vinastiti@umm.ac.id ${ }^{3}$
}

\begin{abstract}
Abstrak
Rekayasa ulang digunakan untuk mengindentifikasi, menganalisa, dan mendesain ulang proses bisnis inti perusahaan/organisasi bertujuan mencapai peningkatan dramatis pada pengukuran kinerja penting seperti biaya, kualitas, layanan dan kecepatan. Pencapaian dilakukan rekayasa ulang yaitu mendukung lebih sebuah misi perusahaan dan mengurangi biaya. UD. Top Stiker adalah salah satu perusahaan yang bergerak di bidang aksesoris telepon genggam, alat tulis dan kantor dan sepeda motor yang saat ini sedang berkembang, sehingga perlu meningkatkan kualitas pelayanan semakin baik. Namun proses bisnis di UD. Top Stiker belum berjalan dengan baik dan memiliki permasalahan yang dapat mengganggu jalannya kegiatan operasional UD. Top Stiker. Menggunakan metode BPR dan analisis SWOT untuk menghasilkan strategi alternatif dan BPMN untuk pemodelan proses bisnis. Penelitian yang digunakan untuk mendapatkan data diperoleh melalui studi kepustakaan, observasi, wawancara dan memberikan kuesioner kepada pemilik UD. Top Stiker. Hasil akhir penelitian ini yang diperoleh adalah sebuah rekomendasi mendesain ulang proses bisnis dengan mengurangi beberapa tahapan proses dari 18 tahapan proses menjadi 13 tahapan proses sehingga menjadi lebih cepa dan sederhana. Sedangkan IFAS faktor kekuatan bernilai 1,55 dan faktor kelemahan bernilai 1,75, untuk EFAS faktor peluang bernilai 1,7 dan faktor ancaman bernilai 1,45.
\end{abstract}

Kata kunci: Rekayasa Ulang, Metode BPR, Analisis SWOT, BPMN.

\begin{abstract}
Re-engineering is used to identify, analyze, and redesign the core bsiness processes of the company/organization aimed at achieving a dramatic increase in critical performance measurements such as cost, quality, service and speed. The achievement of re-engineering is to support more a corporate mission and reduce costs. UD. Top Stiker is one of the companies engaged in the field of mobile phone accessories, stationery and offices and motorcycles are currently developing, so need to improve the quality of service is getting better. But the business process in UD. Top Stiker have not been going well and have problems that can interfere with the running of operational activities UD. Top Stiker. Using the BPR method and SWOT analysis to generate alternative strategies and BPMN for business process modeling. The research used to obtain data was obtained through literature studies, obersvations, interviews and provided questionnaires to UD. Top Stiker owners. The final result of this study was a recommendation of a business process redesign by reducing several process stages from the 18 process stages to 13 process stages sothat become more fast and simple. While value of the IFAS strength factor is 1.55 and the weakness factor is 1.75, while value of the EFAS opportunity factor is 1.7 and risk factor is 1.45 .
\end{abstract}

Keywords: Re-engineering, BPR method, SWOT analysis, BPMN.

\section{Pendahuluan}

Selain pengaruh persaingan dan perubahan kemajuan teknologi, kesuksesan sebuah perusahaan tidak selalu datang dari segi pelayanan produksi dan distribusi, namun menciptakan suatu nilai dan tumbuh untuk melakukan perubahan[1]. Salah satu perubahan tersebut ialah perubahan pada proses bisnisnya[2]. Jika data yang dikelola dengan efisien dan akurat maka dapat mempermudah suatu perusahaan atau organisasi dalam mengendalikan proses bisnis yang berlangsung[3].

UD. Top Stiker adalah salah satu perusahaan yang bergerak di bidang aksesoris telepon genggam, alat tulis dan kantor dan sepeda motor. UD. Top Stiker didirikan pada tahun 2006. UD. 
Top Stiker memiliki beberapa produk yang dijual yaitu stiker, gantungan kunci, vinyldan aksesoris lainnya. Kegiatan operasional di UD. Top Stiker meliputi beberapa aktivitas yaitu penjualan produk, pemesanan produk dan pembayaran produk. Seiring berjalan waktu, UD. Top Stiker mengalami permintaan barang yang meningkat dengan bertambahnya jumlah pelanggan selama beberapa tahun belakang ini.

Namun proses bisnis di UD. Top Stiker belum berjalan dengan baik dan memiliki permasalahan yang dapat mengganggu jalannya kegiatan operasional UD. Top Stiker. Saat ini UD. Top Stiker memiliki keterbatasan dalam melaksanakan kegiatan seperti pemesanan produk yang masih melalui karyawan dan pencatatan pemesanan produk masih menggunakan kertas nota yang di mana berpotensi hilangnya data. UD. Top Stiker belum memanfaatkan teknologi. Hal ini menyebabkan pelanggan susah untuk melakukan pemesanan produk yang harus menunggu karyawan datang berkunjung ke toko terlebih dahulu. Sehingga keterbatasan tersebut dapat berpengaruh pada loyalitas pelanggan. Pelanggan akan mencari pemasok yang bekerja dengan cepat dan tanggap.

Langkah yang diperlukan agar dapat meningkatkan kinerja proses bisnis yaitu dilakukan Rekayasa Ulang (Reengineering), dengan konsep Rekayasa Ulang Proses Bisnis (Business Process Reengineering), yang dimaksudkan dapat memberikan sebuah solusi permasalahan diatas, serta mengurangi kesalahan dalam pencatatan segala transaksi. Rekayasa ulang digunakan untuk mengidentifikasi, menganalisa, dan mendesain ulang proses bisnis inti perusahaan/organisasi bertujuan untuk mencapai peningkatan dramatis pada pengukuran kinerja penting seperti biaya, kualitas, layanan dan kecepatan. Pencapaian dilakukan rekayasa ulang yaitu mendukung lebih sebuah misi perusahaan dan mengurangi biaya[4].

Perusahaan atau organisasi dalam menghadapi persaingan pasar, tidak hanya mengupayakan untuk memperbaiki pelayanan kepada pelanggan, namun harus mengetahui kekuatan internal dan eksternal yang ada sehingga perusahaan/organisasi dapat bersaing dengan pesaing. Mengetahui faktor eksternal dan faktor internal lingkungan merupakan suatu kunci penting untuk perusahaan atau organisasi[5]. Oleh karena itu, perusahaan atau organisasi menggunakan analisis SWOT untuk menentukan faktor eksternal ancaman dan peluang dan menentukan faktor internal kekuatan dan kelemahan perusahaan/organisasi. Analisis SWOT adalah konsep yang digunakan untuk menunjukkan faktor eksternal dan faktor internal secara menyeluruh pada perusahaan atau organisasi[6].

Salah satu kekuatan pada UD. Top Stiker adalah penawaran harga yang terjangkau, kontrol kualitas yang tinggi, jaringan pendistribusian yang luas dan produk yang dijual beraneka ragam. Untuk kelemahan pada UD. Top Stiker adalah kurangnya karyawan yang bekerja di UD. Top Stiker, jadwal penagihan produk tidak menentu yang sering disebabkan toko tidak buka atau karyawan tidak masuk kerja, pemesanan produk yang masih manual sehingga pesanan produk hanya bisa dilakukan ketika karyawan mendatangi toko dan ini berlaku dengan pembayaran produk, tidak ada komunikasi atau kabar terlebih dahulu dari pihak pemilik toko kepada UD. Top Stiker apabila toko tutup atau pindah sehingga sering terjadi produk tidak dapat diambil atau ditarik kembali. Sedangkan peluang pada UD. Top Stiker adalah semakin hari banyak bermunculan toko fotokopi atau toko alat tulis, toko pulsa dan bengkel yang belum pernah dititipkan produk sehingga dapat menambah pendapatan dan jumlah pelanggan, permintaan akan aksesoris telepon genggam, sepeda motor semakin meningkat, permintaan barang yang meningkat dan telah memiliki banyak pelanggan tetap. Selain itu, ancaman pada UD. Top Stiker adalah munculnya pesaing yang menjual produk sejenis, belum menggunakan informasi teknologi dalam menunjang kegiatan operasional, semakin tingginya biaya operasional, persaingan harga dan kualitas produk.

Pada penelitian[7] proses administrasi tugas akhir yang dilakukan oleh mahasiswa memiliki beberapa proses aktivitas terkait dengan partisipan untuk melakukan bimbingan. Banyak partisipan yang mengikuti menyebabkan waktu yang terpakai. Sehingga dilakukan rekayasa ulang bertujuan untuk mengurangi waktu yang terpakai dengan meningkatkan kinerja sistem informasi dengan metode konsolidasi. Kemudian penelitian[8] proses rekayasa ulang dilakukan dikarenakan banyaknya proses bisnis yang masih manual, selain itu terdapat kelemahan dan ancaman yang terjadi pada penelitian tersebut membuat peneliti melakukan rekayasa ulang proses bisnis dengan menggunakan metode analisis SWOT untuk melakukan desain ulang proses. Hasil penelitian tersebut adalah membangun sistem informasi perusahaan berbasis website. Penelitian memanfaatkan metode SWOT saat dilakukan proses bisnis untuk mendapatkan penilaian organisasi di kursus informatika untuk program pascasarjana perawat.

REPOSITOR, Vol. 2, No. 10, Oktober 2020, Pp. 1309-1320 
Berdasarkan permasalahan yang ada pada UD. Top Stiker, penelitian ini mengambil judul "Analisa Rekayasa Ulang Proses Bisnis Pada UD. Top Stiker" yang menggunakan konsep perancangan ulang proses bisnis dan analisis SWOT tujuan mengatasi permasalahan yang sedang berlangsung dengan memberikan rekomendasi proses bisnis baru untuk UD. Top Stiker.

\section{Metode Penelitian}

Tahapan dalam penelitian yang akan dilakukan adalah :
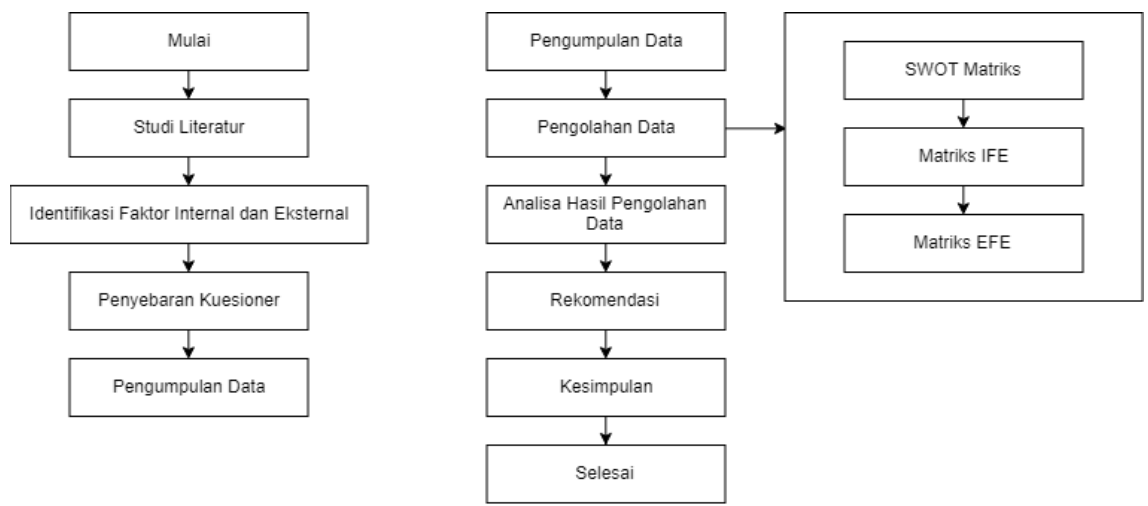

Gambar 2.1 Metode Penelitian

\subsection{Studi Literatur}

Studi literatur adalah mengambil sumber data yang diperoleh dari mempelajari dan membaca hasil penelitian, buku-buku, jurnal atau berbagai literatur yang berhubungan mengenai Business Process Reengineering, analisis SWOT yang sebagai pendukung pelaksanaan tugas akhir.

\subsection{Identifikasi Faktor Internal dan Eksternal}

Identifikasi faktor internal dan eksternal pada UD. Top Stiker dapat dilakukan dengan menggunakan analisis SWOT, yang di mana mengidentifikasi berbagai faktor secara sistematis. Analisis faktor internal dan eksternal digunakan untuk mengetahui faktor internal kekuatan dan kelemahan yang dapat mempengaruhi pada pengembangan bisnis dan faktor eksternal dalam menemukan dan menentukan peluang dan dapat menghindari ancaman pada pengembangan usaha. Identifikasi faktor internal dan faktor eksternal akan dilakukan dengan menggunakan analisis internal factor evaluation (IFE) dan ekstenal factor evaluation (EFE)[9].

\subsection{Penyebaran Kuesioner}

Penyebaran kuesioner akan diberikan kepada responden yaitu pemilik perusahaan UD. Top Stiker. Responden tersebut terpilih berdasarkan keterkaitan dalam penelitian ini dan mempunyai pemahaman dan pengetahuan yang baik.

\subsection{Pengumpulan Data} data yaitu:

Pada tahap pelaksanaan penelitian ini, terdapat langkah-langkah dalam mengumpulkan

\section{Wawancara}

Wawancara merupakan teknik mengumpulkan informasi yang mana mengajukan pertanyaan kepada yang bersangkutan yang dijawab secara lisan untuk menjawab permasalahan penelitian secara langsung, dengan dibantu kuesioner. Pada pelaksanaan penelitian ini, wawancara dilakukan kepada pemilik UD. Top Stiker yang bertujuan memperoleh data mengenai pelaksanaan proses bisnis UD. Top Stiker.

\section{Observasi}

Observasi merupakan teknik mengumpulkan informasi yang mana melalui pengamatan pada obyek yang diteliti secara langsung untuk mengetahui dan mengamati fenomena yang sebenarnya di lapangan. Observasi penelitian ini dilakukan untuk mengetahui proses bisnis secara langsung yang sedang terjadi di UD. Top Stiker sehingga dapat menemukan fakta dan mengidentifikasi proses bisnis yang harus dilakukan perbaikan. 
3. Kuesioner

Kuesioner merupakan teknik mengumpulkan informasi yang mana responden melakukan pengisian kuesinoner yang berisi beberapa pertanyaan mengenai permasalahan dalam penelitian. Penggunaan teknik kuesioner pada penelitian ini digunakan untuk menggali informasi mengenai kekuatan dan kelemahan dari faktor internal UD. Top Stiker, peluang dan ancaman dari faktor eksternal UD. Top Stiker. Responden yang dipilih yaitu pemilik UD. Top Stiker yang mana pemilihan responden ini dikarenakan memiliki pengetahuan, keahlian, dan pengalaman terkait penelitian ini.

\subsection{Pengolahan Data}

Analisa data dalam penelitian ini menggunakan analisis SWOT yang bertujuan menganalisis faktor internal kekuatan dan kelemahan dengan faktor eskternal peluang dan ancaman pada UD. Top Stiker secara sistematis dengan metode pendekatan deskriptif. Berdasarkan hasil analisis SWOT akan dilakukan pengambilan keputusan strategi dengan menggunakan matriks SWOT. Matrik SWOT digunakan untuk membandingkan kedua faktor tersebut.

Tahapan yang akan dilakukan pada penelitian ini sebagai berikut:

\section{Matriks Internal Faktors Evaluation (IFE)}

IFE merupakan analisis yang menggunakan kekuatan dan kelemahan yang dimiliki dari lingkungan internal perusahaan untuk dilakukan perumusan faktor-faktor internal perusahaan[10]. Berikut tahapan penyusunannya:

1. Identifikasi faktor kekuatan dan faktor kelemahan pada tabel Matriks IFE di kolom 1. Tulis 5 sampai dengan 10 faktor yang menjadi kekuatan dan kelemahan.

2. Tulis bobot masing-masing faktor strategis dengan skala 1,0 (sangat penting) sampai 0,0 (tidak penting) di kolom 2. Keseluruhan jumlah bobot tidak boleh melebihi total skor = 1,00. Pengaruh posisi strategis mendasari untuk memberikan bobot pada faktor.

3. Tulis rating masing-masing faktor strategis dengan skala yang dimulai dari 4 (sangat kuat) sampai 1 (lemah) pada kolom 3 , pemberian rating didasarkan pengaruh faktor pada kondisi UD. Top Stiker.

4. Hitung bobot dengan rating untuk mendapatkan hasil berupa skor pembobotan yang nilainya bermacam pada kolom 4 .

5. Menjumlahkan skor pembobotan untuk mendapatkan total skor pembobotan pada kolom 4.

\section{Matriks Eksternal Faktors Evaluation (EFE)}

EFE merupakan analisis yang menggunakan peluang dan ancaman yang dimiliki dari lingkungan eksternal perusahaan untuk dilakukan perumusan faktor-faktor perusahaan[10]. Berikut tahapan penyusunannya:

1. Identifikasi faktor peluang dan faktor ancaman pada tabel Matriks EFE di kolom 1. Tulis 5 sampai dengan 10 faktor yang menjadi peluang dan ancaman.

2. Tulis bobot masing-masing faktor strategis dengan skala 1,0 (sangat penting) sampai 0,0 (tidak penting) di kolom 2. Keseluruhan jumlah bobot tidak boleh melebihi total skor = 1,00. Pengaruh posisi strategis mendasari untuk memberikan bobot pada faktor.

3. Tulis rating masing-masing faktor strategis dengan skala yang dimulai dari 4 (sangat kuat) sampai 1 (lemah) pada kolom 3 , pemberian rating didasarkan pengaruh faktor pada kondisi UD. Top Stiker.

4. Hitung bobot dengan rating untuk mendapatkan hasil berupa skor pembobotan yang nilainya bermacam pada kolom 4 .

5. Menjumlahkan skor pembobotan untuk mendapatkan total skor pembobotan pada kolom 4.

\section{Matriks SWOT}

Matrik SWOT menunjukkan bahwa bagaimana perusahaan menghadapi peluang dan ancaman faktor internal dengan kekuatan dan kelemahan faktor internal yang dimiliki perusahaan. Terdapat berbagai macam strategi yaitu strategi SO, strategi WO, strategi ST, dan strategi WT. Pada matrik ini akan menghasilkan empat sel kemungkinan alternatif strategi. 


\subsection{Analisa Hasil Pengolahan Data}

Pada tahap ini, akan dilakukan analisa lebih dalam berdasarkan hasil pengolahan data yang diperoleh dari penggunaan metode matriks internal-eksternal, matriks SWOT, dan diagram SWOT.

\subsection{Rekomendasi}

Rekomendasi yang merupakan hasil analisis yang bertujuan dapat mempertahankan kekuatan atau memberikan keuntungan sebanyak-banyaknya dari peluang yang dimiliki, sehingga dapat mengurangi kekurangan dan mengatasi ancaman.

\section{Hasil Penelitian dan Pembahasan}

\subsection{Identifikasi Faktor Internal dan Eksternal Pada UD. Top Stiker}

Mengidentifikasi faktor lingkungan perusahaan yang terdiri dari dua jenis yaitu faktor lingkungan eksternal dan lingkungan internal. Berdasarkan hasil identifikasi yang diperoleh dari wawancara kepada pemilik dan lapangan.

\subsubsection{Identifikasi Faktor Internal}

Berikut faktor strategi internal yang dapat menjadi kekuatan dan kelemahan oleh UD. Top Stiker sebagai berikut :

a. Kekuatan yang dimiliki oleh UD. Top Stiker sebagai berikut :

1) Penawaran harga yang terjangkau dikalangan konsumen

2) Perusahaan melakukan kontrol kualitas yang tinggi pada semua produk

3) Perusahaan memiliki nama baik di konsumen

4) Lokasi perusahaan yang strategis

5) Memiliki jaringan pendistribusian yang luas

6) Menjual produk yang beraneka ragam

b. Kelemahan yang dimiliki oleh UD. Top Stiker sebagai berikut :

1) Terbatasnya tenaga sales pada perusahaan

2) Transaksi masih bergantung penuh pada sales

3) Kurangnya promosi

4) Manajemen keuangan yang masih dilakukan secara konvensional

5) Kegiatan penagihan barang dan retur barang tidak terjadwal atau tidak menentu

6) Perusahaan belum memanfaatkan teknologi

Berikut merupakan faktor Internal kekuatan dan kelemahan pada UD. Top Stiker:

Tabel 3.1 Faktor Internal UD. Top Stiker

\begin{tabular}{|l|l|}
\hline & Kekuatan \\
\hline S1 & Penawaran harga yang terjangkau dikalangan konsumen \\
\hline S2 & Perusahaan melakukan kontrol kualitas yang tinggi pada semua produk \\
\hline S3 & Perusahaan memiliki nama baik di konsumen \\
\hline S4 & Lokasi perusahaan yang strategis \\
\hline S5 & Memiliki jaringan pendistribusian yang luas \\
\hline S6 & Menjual produk yang beraneka ragam \\
\hline
\end{tabular}

Tabel 3.2 Faktor Internal UD. Top Stiker

\begin{tabular}{|l|l|}
\hline & Kelemahan \\
\hline W1 & Terbatasnya tenaga sales pada perusahaan \\
\hline W2 & Transaksi masih bergantung penuh pada sales \\
\hline W3 & Kurangnya promosi \\
\hline W4 & Manajemen keuangan yang masih dilakukan secara konvensional \\
\hline W5 & Kegiatan penagihan barang dan retur barang tidak terjadwal atau tidak menentu \\
\hline W6 & Perusahaan belum memanfaatkan teknologi \\
\hline
\end{tabular}

\subsubsection{Identifikasi Faktor Eksternal}

Berikut faktor strategi eksternal yang dapat menjadi peluang dan ancaman oleh UD. Top Stiker sebagai berikut :

a. Peluang yang dimiliki oleh UD. Top Stiker sebagai berikut : 

1) Mendapatkan respon baik dari konsumen
2) Terjadi permintaan barang yang meningkat
3) Terjalin hubungan yang baik antara pemilik perusahaan dan pelanggan
4) Memiliki pelanggan tetap
5) Menjamurnya toko baru di sekitar perusahaan
6) Terjalin hubungan yang baik antara pemilik perusahaan dan pemasok

b. Ancaman yang dimiliki oleh UD. Top Stiker sebagai berikut :

1) Munculnya pesaing yang menjual produk sejenis

2) Permintaan pasar yang cepat berganti mengikuti tren

3) Semakin tinggi biaya operasional

4) Terjadi persaingan harga dan kualitas produk

5) Terjadinya persaingan pada pelayanan

6) Terjadinya pemberian promosi pada pesaing Berikut merupakan faktor Ekternal peluang dan ancaman pada UD. Top Stiker:

Tabel 3.3 Faktor Eksternal UD. Top Stiker

\begin{tabular}{|l|l|}
\hline & Peluang \\
\hline O1 & Mendapatkan respon baik dari konsumen \\
\hline O2 & Terjadi permintaan barang yang meningkat \\
\hline O3 & Terjalin hubungan yang baik antara pemilik perusahaan dan pelanggan \\
\hline O4 & Memiliki pelanggan tetap \\
\hline O5 & Menjamurnya toko baru di sekitar perusahaan \\
\hline O6 & Terjalin hubungan yang baik antara pemilik perusahaan dan pemasok \\
\hline
\end{tabular}

Tabel 3.4 Faktor Eksternal UD. Top Stiker

\begin{tabular}{|l|l|}
\hline & Ancaman \\
\hline T1 & Munculnya pesaing yang menjual produk sejenis \\
\hline T2 & Permintaan pasar yang cepat berganti mengikuti tren \\
\hline T3 & Semakin tinggi biaya operasional \\
\hline T4 & Terjadi persaingan harga dan kualitas produk \\
\hline T5 & Terjadinya persaingan pada pelayanan \\
\hline T6 & Terjadinya pemberian promosi pada pesaing \\
\hline
\end{tabular}

\subsection{Pengambilan dan Pengolahan Data}

Pada langkah ini kuesioner dari pihak UD. Top Stiker akan digunakan untuk melakukan pembobotan dan rating faktor internal dan faktor eksternal yang kemudian digunakan dalam menentukan strategi UD. Top Stiker.

Tabel 3.5 Hasil Kuesioner Pembobotan Faktor Internal Pada UD. Top Stiker

\begin{tabular}{|c|c|c|c|}
\hline NO & IFAS & Bobot & Rating \\
\hline & \multicolumn{3}{|l|}{ Faktor Internal Kekuatan } \\
\hline 1. & Penawaran harga yang terjangkau dikalangan konsumen & 0,10 & 4 \\
\hline 2. & Perusahaan melakukan kontrol kualitas yang tinggi pada semua produk & 0,05 & 2 \\
\hline 3. & Perusahaan memiliki nama baik di konsumen & 0,10 & 4 \\
\hline 4. & Lokasi perusahaan yang strategis & 0,05 & 2 \\
\hline 5. & Memiliki jaringan pendistribusian yang luas & 0,10 & 4 \\
\hline \multirow[t]{2}{*}{6.} & Menjual produk yang beraneka ragam & 0,05 & 3 \\
\hline & \multicolumn{3}{|l|}{ Faktor Internal Kelemahan } \\
\hline 1. & Terbatasnya tenaga sales pada perusahaan & 0,05 & 3 \\
\hline 2. & Transaksi masih bergantung penuh pada sales & 0,10 & 4 \\
\hline 3. & Kurangnya promosi & 0,05 & 2 \\
\hline 4. & Manajemen keuangan yang masih dilakukan secara konvensional & 0,10 & 2 \\
\hline 5. & $\begin{array}{l}\text { Kegiatan penagihan barang dan retur barang tidak terjadwal atau tidak } \\
\text { menentu }\end{array}$ & 0,10 & 3 \\
\hline 6. & Perusahaan belum memanfaatkan teknologi & 0,15 & 4 \\
\hline
\end{tabular}

REPOSITOR, Vol. 2, No. 10, Oktober 2020, Pp. 1309-1320 


$1,00 \quad 37$

Tabel 3.6 Hasil Kuesioner Pembobotan Faktor Eksternal Pada UD. Top Stiker

\begin{tabular}{|c|c|c|c|}
\hline NO & EFAS & Bobot & Rating \\
\hline & \multicolumn{3}{|l|}{ Faktor Eksternal Peluang } \\
\hline 1. & Mendapatkan respon baik dari konsumen & 0,10 & 3 \\
\hline 2. & Terjadi permintaan barang yang meningkat & 0,05 & 2 \\
\hline 3. & Terjalin hubungan yang baik antara pemilik perusahaan dan pelanggan & 0,05 & 2 \\
\hline 4. & Memiliki pelanggan tetap & 0,10 & 4 \\
\hline 5. & Menjamurnya toko baru di sekitar perusahaan & 0,10 & 2 \\
\hline \multirow[t]{2}{*}{6.} & Terjalin hubungan yang baik antara pemilik perusahaan dan pemasok & 0,15 & 4 \\
\hline & \multicolumn{3}{|l|}{ Faktor Eksternal Ancaman } \\
\hline 1. & Munculnya pesaing yang menjual produk sejenis & 0,15 & 4 \\
\hline 2. & Permintaan pasar yang cepat berganti mengikuti tren & 0,05 & 2 \\
\hline 3. & Semakin tinggi biaya operasional & 0,10 & 4 \\
\hline 4. & Terjadi persaingan harga dan kualitas produk & 0,05 & 3 \\
\hline 5. & Terjadinya persaingan pada pelayanan & 0,05 & 2 \\
\hline 6. & Terjadinya pemberian promosi pada pesaing & 0,05 & 2 \\
\hline & Total & 1,00 & 34 \\
\hline
\end{tabular}

a. Matriks IFAS (Internal Faktor Analysis Summary)

Data yang diperoleh merupakan dari hasil kuesioner faktor internal dan kuesioner penilaian skor faktor insternal UD. Top Stiker akan dimasukkan ke dalam matriks IFAS. Perumusannya yaitu dengan cara bobot dikalikan rating.

Tabel 3.7 Matriks IFAS (Internal Faktor Analysis Summary) UD. Top Stiker

\begin{tabular}{|l|l|l|l|l|l|}
\hline NO & Pertanyaan & \multicolumn{2}{l|}{ Bobot } & Rating & Bobotx Rating \\
\hline Faktor Internal Kekuatan (Strength) & $\begin{array}{l}\text { Penawaran harga yang terjangkau dikalangan } \\
\text { konsumen }\end{array}$ & 0,10 & 4 & 0,4 \\
\hline 2. & $\begin{array}{l}\text { Perusahaan melakukan kontrol kualitas yang tinggi } \\
\text { pada semua produk }\end{array}$ & 0,05 & 2 & 0,1 \\
\hline 3. & Perusahaan memiliki nama baik di konsumen & 0,10 & 4 & 0,4 \\
\hline 4. & Lokasi perusahaan yang strategis & 0,05 & 2 & 0,1 \\
\hline 5. & Memiliki jaringan pendistribusian yang luas & 0,10 & 4 & 0,4 \\
\hline 6. & Menjual produk yang beraneka ragam & 0,05 & 3 & 0,15 \\
\hline Faktor Internal Kelemahan (Weaknesses) & & & $\mathbf{1 , 5 5}$ \\
\hline 1. & Terbatasnya tenaga sales pada perusahaan & 0,05 & 3 & 0,15 \\
\hline 2. & Transaksi masih bergantung penuh pada sales & 0,10 & 4 & 0,4 \\
\hline 3. & Kurangnya promosi & 0,05 & 2 & 0,1 \\
\hline 4. & $\begin{array}{l}\text { Manajemen keuangan yang masih dilakukan secara } \\
\text { konvensional }\end{array}$ & 0,10 & 2 & 0,2 \\
\hline 5. & $\begin{array}{l}\text { Kegiatan penagihan barang dan retur barang tidak } \\
\text { terjadwal atau tidak menentu }\end{array}$ & 0,10 & 3 & 0,3 \\
\hline 6. & Perusahaan belum memanfaatkan teknologi & 0,15 & 4 & 0,6 \\
\hline & Subtotal & & $\mathbf{1 , 7 5}$ \\
\hline & Total IFAS & & $\mathbf{3 , 3}$ \\
\hline
\end{tabular}


b. Matriks EFAS (Eksternal Faktor Analysis Summary)

Data yang diperoleh merupakan dari hasil kuesioner faktor eksternal dan kuesioner penilaian skor faktor eksternal UD. Top Stiker akan dimasukkan ke dalam matriks EFAS. Perumusannya yaitu dengan cara bobot dikalikan rating.

Tabel 3.8 Matriks EFAS (Eksternal Faktor Analysis Summary) UD. Top Stiker

\begin{tabular}{|c|c|c|c|c|}
\hline NO & Pertanyaan & Bobot & Rating & Bobot x Rating \\
\hline \multicolumn{5}{|c|}{ Faktor Eksternal Peluang (Opportunities) } \\
\hline 1. & Mendapatkan respon baik dari konsumen & 0,10 & 3 & 0,3 \\
\hline 2. & Terjadi permintaan barang yang meningkat & 0,05 & 2 & 0,1 \\
\hline 3. & $\begin{array}{l}\begin{array}{l}\text { Terjalin hubungan yang baik antara } \\
\text { perusahaan dan pelanggan }\end{array} \\
\text { pemilik }\end{array}$ & 0,05 & 2 & 0,1 \\
\hline 4. & Memiliki pelanggan tetap & 0,10 & 4 & 0,4 \\
\hline 5. & Menjamurnya toko baru di sekitar perusahaan & 0,10 & 2 & 0,2 \\
\hline \multirow[t]{2}{*}{6.} & $\begin{array}{l}\text { Terjalin hubungan yang baik antara pemilik } \\
\text { perusahaan dan pemasok }\end{array}$ & 0,15 & 4 & 0,6 \\
\hline & Subtotal & & & 1,7 \\
\hline \multicolumn{5}{|c|}{ Faktor Eksternal Ancaman (Threat) } \\
\hline 1. & Munculnya pesaing yang menjual produk sejenis & 0,15 & 4 & 0,6 \\
\hline 2. & Permintaan pasar yang cepat berganti mengikuti tren & 0,05 & 2 & 0,1 \\
\hline 3. & Semakin tinggi biaya operasional & 0,10 & 4 & 0,4 \\
\hline 4. & Terjadi persaingan harga dan kualitas produk & 0,05 & 3 & 0,15 \\
\hline 5. & Terjadinya persaingan pada pelayanan & 0,05 & 2 & 0,1 \\
\hline 6. & Terjadinya pemberian promosi pada pesaing & 0,05 & 2 & 0,1 \\
\hline & \multicolumn{3}{|l|}{ Subtotal } & 1,45 \\
\hline & \multicolumn{3}{|l|}{ Total EFAS } & 3,15 \\
\hline
\end{tabular}

Setelah dilakukan tahapan pembobotan dan rating IFE dan EFE maka diperoleh data yang menunjukkan bahwa hasil matriks internal faktor kekuatan dan kelemahan yaitu 3.3, sedangkan untuk hasil matriks eksternal faktor peluang dan ancaman yaitu 3,15 .

\section{c. Diagram Kartesius Analisis SWOT}

Pada tahap sebelumnya, telah diketahui total skor masing-masing faktor. Faktor kekuatan mendapatkan total skor sebesar 1,55, faktor kelemahan mendapatkan total skor sebesar 1,75, faktor peluang mendapatkan total skor sebesar 1,7, faktor ancaman mendapatkan total skor sebesar 1,45. Selisih total skor faktor kekuatan dan faktor kelemahan sebesar (-)0,2, sedangkan selisih total skor faktor peluang dan faktor ancaman sebesar (+)0,25. Berikut merupakan penggambaran diagram kartesius analisis SWOT :

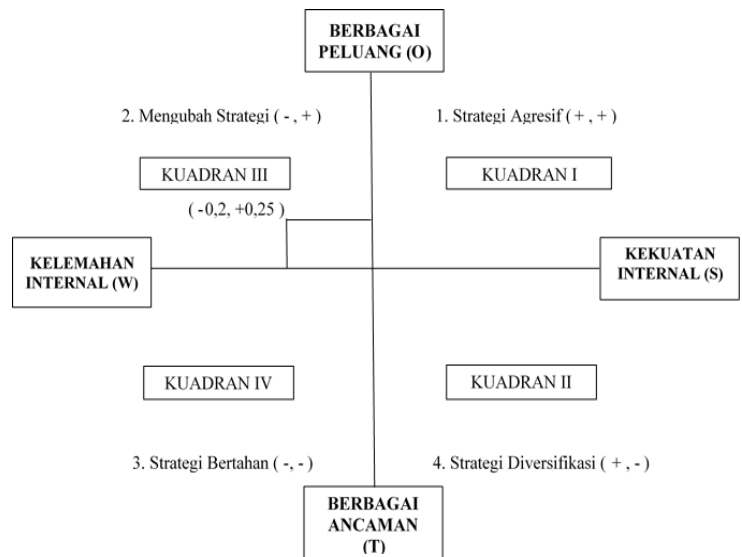

Gambar 3.1 Diagram Cartesius Analisis SWOT UD. Top Stiker

REPOSITOR, Vol. 2, No. 10, Oktober 2020, Pp. 1309-1320 
Berdasarkan hasil gambar diagram cartesius, menunjukkan bahwa UD. Top Stiker berada pada kuadran III yang dimana kuadran tersebut kondisi perusahaan sangat lemah tetapi memiliki peluang yang besar untuk bisa berkembang, dengan cara melakukan perubahan strategi lama dan meminimalkan kelemahan yang ada yang dikarenakan perusahaan akan sulit mendapatkan peluang yang ada.

\section{d. Matriks SWOT}

Tabel 3.9 Matriks SWOT UD. Top Stiker

\begin{tabular}{|c|c|c|}
\hline ernal & $\begin{array}{l}\text { Strengths: } \\
\text { 1. Penawaran harga yang } \\
\text { terjangkau dikalangan } \\
\text { konsumen. } \\
\text { 2. Perusahaan melakukan } \\
\text { kontrol kualitas yang tinggi } \\
\text { pada semua produk. } \\
\text { 3. Perusahaan memiliki } \\
\text { nama baik di konsumen. } \\
\text { 4. Lokasi perusahaan yang } \\
\text { strategis. jaringan } \\
\text { 5. Memiliki yendistribusian yang luas. } \\
\text { pendis produk yang } \\
\text { 6. Menjual proan } \\
\text { beraneka ragam }\end{array}$ & $\begin{array}{l}\text { Weaknesses: } \\
\text { 1. Terbatasanya tenaga } \\
\text { sales pada perusahaan. } \\
\text { 2. Transaksi masih } \\
\text { bergantung penuh pada } \\
\text { sales. } \\
\text { 3. Kurangnya promosi. } \\
\text { 4. Manajemen keuangan } \\
\text { yang masih dilakukan } \\
\text { secara konvensional. } \\
\text { 5. Kegiatan penagihan } \\
\text { barang dan retur barang } \\
\text { tidak terjadwal atau tidak } \\
\text { menentu. } \\
\text { 6. Perusahaan belum } \\
\text { memanfaatkan teknologi. }\end{array}$ \\
\hline $\begin{array}{l}\text { Opportunities: } \\
\text { 1. Mendapatkan respon baik } \\
\text { dari konsumen. } \\
\text { 2. Terjadi permintaan } \\
\text { barang yang meningkat } \\
\text { 3. Terjalin hubungan yang } \\
\text { baik antara pemilik } \\
\text { perusahaan dan } \\
\text { pelanggan. } \\
\text { 4. Memiliki pelanggan tetap. } \\
\text { 5. Menjamurnya toko baru di } \\
\text { sekitar perusahaan. } \\
\text { 6. Terjalin hubungan yang } \\
\text { baik antara pemilik } \\
\text { perusahaan dan } \\
\text { pemasok. }\end{array}$ & $\begin{array}{l}\text { Strategi SO: } \\
\text { 1. Memanfaatkan } \\
\text { penawaran harga guna } \\
\text { meningkatkan omzet } \\
\text { penjualan. } \\
\text { 2. Memperluas jangkauan } \\
\text { pendistribusian atau } \\
\text { penjualan produk. } \\
\text { 3. Mempertahankan kualitas } \\
\text { produk. } \\
\text { 4. Menjamin kualitas produk } \\
\text { dengan dilakukan } \\
\text { pemeriksaan setiap } \\
\text { produk. }\end{array}$ & $\begin{array}{l}\text { Strategi WO: } \\
\text { 1. Menambah tenaga kerja } \\
\text { atau sales dan armada. } \\
\text { 2. Mengadakan promosi } \\
\text { untuk menarik pelanggan. } \\
\text { 3. Dapat melakukan } \\
\text { transaksi secara offline } \\
\text { atau online. } \\
\text { 4. Mendatangi toko baru } \\
\text { untuk menambah } \\
\text { pelanggan baru. } \\
\text { 5. Memperbaiki sistem } \\
\text { administrasi. }\end{array}$ \\
\hline $\begin{array}{l}\text { Threats: } \\
\text { 1. Munculnya pesaing yang } \\
\text { menjual produk sejenis. } \\
\text { 2. Permintaan pasar yang } \\
\text { cepat berganti mengikuti } \\
\text { tren. } \\
\text { 3. Semakin tinggi biaya } \\
\text { operasional } \\
\text { 4. Terjadi persaingan harga } \\
\text { dan kualitas produk } \\
\text { 5. Terjadinya persaingan } \\
\text { pada pelayanan. } \\
\text { 6. Terjadinya pemberian } \\
\text { promosi pada pesaing. }\end{array}$ & $\begin{array}{l}\text { Strategi ST: } \\
\text { 1. Melakukan inovasi produk } \\
\text { yang bermacam-macam. } \\
\text { 2. Memperbaiki pelayanan } \\
\text { kepada pelanggan. } \\
\text { 3. Melakukan pemasaran } \\
\text { dengan cara jemput bola. } \\
\text { 4. Mempertahankan } \\
\text { loyalitas kepada } \\
\text { pelanggan. }\end{array}$ & $\begin{array}{l}\text { Strategi WT: } \\
\text { 1. Memanfaatkan teknologi } \\
\text { untuk memperlancar } \\
\text { transaksi. } \\
\text { 2. Memperbaiki penjadwalan } \\
\text { kunjungan ke pelanggan } \\
\text { secara rutin. }\end{array}$ \\
\hline
\end{tabular}

\subsection{Rekomendasi}

Berdasarkan hasil analisis matriks SWOT yang telah dilakukan bahwa perusahaan berada di kuadran III, yang dimana kondisi perusahaan sangat lemah tetapi memiliki peluang 
yang besar untuk bisa berkembang, sehingga perlu dilakukan perubahan strategi. Hasil analisis SWOT dapat menjadi pedoman untuk melakukan rekomendasi perubahan strategi. Salah satu perubahan strategi yang dilakukan yaitu dengan melakukan perancangan ulang proses bisnis pada proses transaksi. Perancangan ulang proses bisnis ini bertujuan untuk mengurangi waktu tunggu yang lama. Berikut tahapan melakukan perancangan ulang proses bisnis[30]:

1. Penentuan proses bisnis saat ini

Mengidentifikasi proses bisnis yang ada saat ini dan informasi dasar yang dibutuhkan untuk membuat proses bisnis baru. Pada proses bisnis yang sedang berjalan saat ini, terdapat 4 orang yang terlibat dalam proses tersebut dan yaitu:

1. Pemilik. Seseorang yang memberikan nota penjualan dan katalog produk kepada karyawan, memproses pemesanan produk yang kemudian diberikan kepada bagian pengemasan produk.

2. Pengemasan produk. Seseorang yang mendapatkan tugas dari pemilik untuk melakukan pengemasan produk baik merupakan produk pesanan atau produk yang akan di distribusikan yang kemudian diberikan kepada sales.

3. Sales. Seseorang yang diberi tugas oleh pemilik untuk mendatangi toko, yang kemudian memberikan nota penjualan, mengganti produk lama dan memberikan katalog produk dan nota pesanan kepada pelanggan.

4. Pelanggan. Seseorang yang melakukan pemesanan produk dan pembayaran produk yang terjual melalui sales.

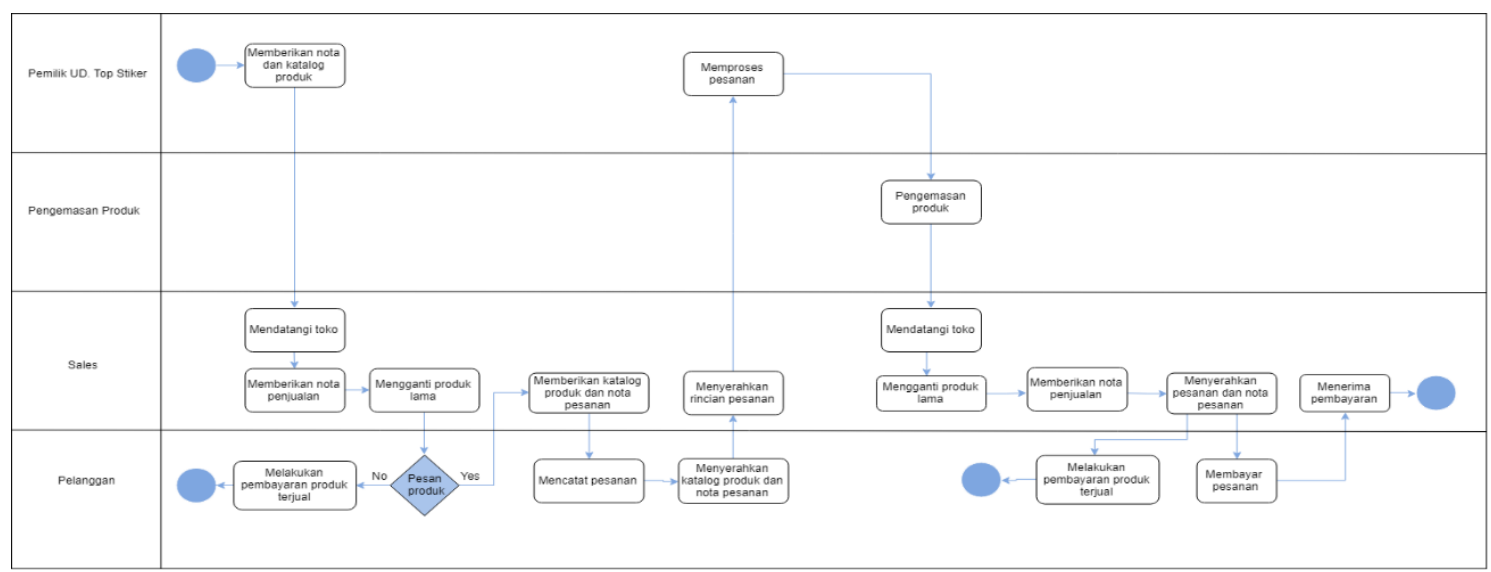

Gambar 3.2 Pemodelan proses bisnis saat ini

2. Menganalisis proses bisnis saat ini

Adapun analisis informasi yang telah dirangkum yaitu:

1. Proses yang tidak diperlukan dengan beberapa tahapan.

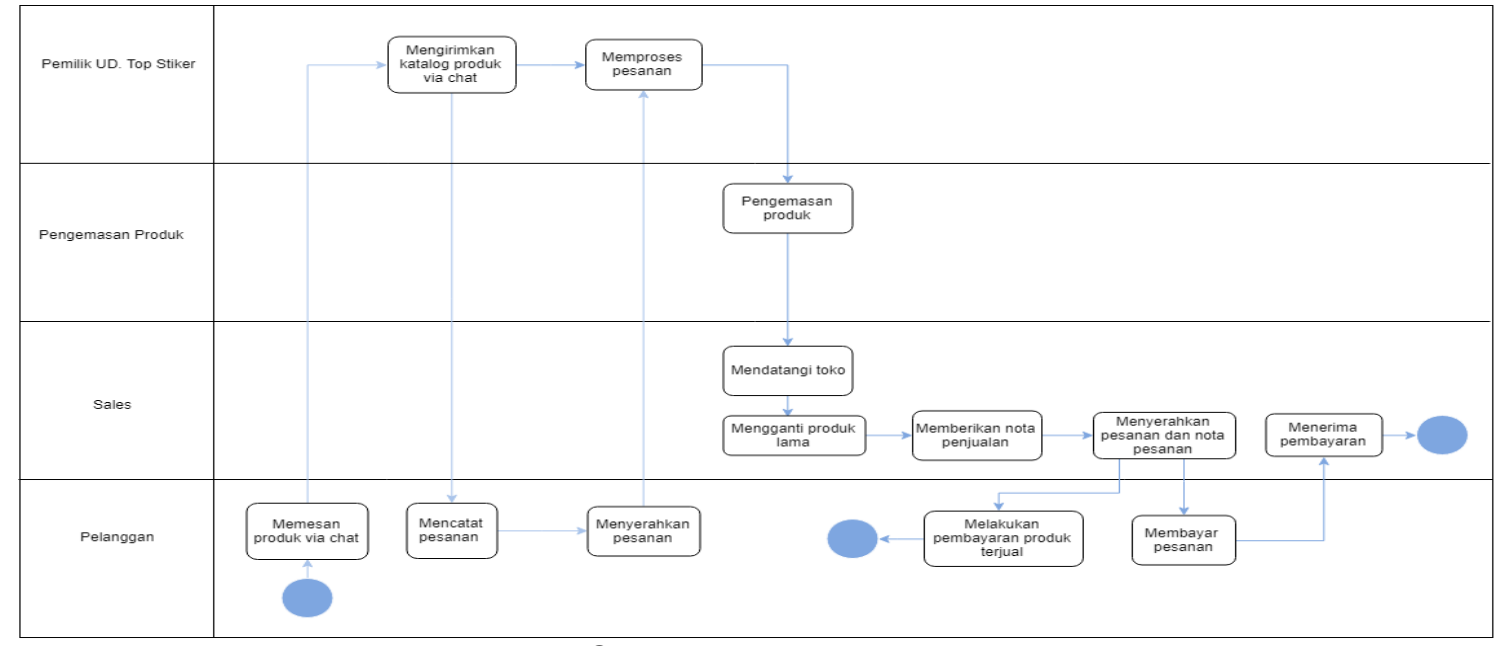

Gambar 3.3 Pemodelan proses bisnis baru

2. Adanya peraturan tertentu yang menyebabkan terjadinya waktu tunggu.

REPOSITOR, Vol. 2, No. 10, Oktober 2020, Pp. 1309-1320 
Solusi yang dapat diberikan yaitu:

1. Melakukan penyisihan proses yang tidak diperlukan.

2. Melakukan perubahan proses untuk mengurangi waktu tunggu.

3. Melakukan perubahan pembatasan peraturan yang terjadi pada proses saat ini.

3. Melakukan proses mendesain ulang.

Pada tahapan-tahapan yang telah dilakukan, hasilnya menunjukkan bahwa terdapat langkah proses yang tidak diperlukan berjumlah 5 langkah proses, dan semua proses dapat berubah karena tidak terikat oleh peraturan kebijakan. Proses baru yang telah dilakukan pengurangan berjumlah 13 tahapan proses dari 18 tahapan proses yang lama. Proses baru dapat digambarkan melalui peran aktor sebagai berikut:

1. Pelanggan. Seseorang yang memesan produk melalui via chat.

2. Pemilik. Seseorang yang mengirimkan katalog produk via chat kepada pelanggan dan melakukan pemrosesan pesanan yang akan diberikan kepada bagian pengemasan produk.

3. Pengemasan produk. Seseorang yang diberikan tugas oleh pemilik untuk melakukan pengemasan produk yang kemudian diberikan kepada sales.

4. Sales. Seseorang yang akan mendatangi toko, mengganti produk lama, dan menyerahkan pesanan serta rincian pembayaran pesanan kepada pelanggan.

4. Pelaksanaan proses bisnis baru.

Setelah dilakukan analisi data, ditemukan beberapa proses yang tidak diperlukan dan memakan waktu yang lama. Setelah pelaksanaan proses bisnis baru, telah terjadi pengurangan waktu seperti yang terlihat pada tabel 3.11 dan 3.12.

Tabel 3.11 Waktu yang digunakan pada proses saat ini.

\begin{tabular}{|l|l|}
\hline Jenis Layanan & Proses Saat Ini (menit) \\
\hline Memberikan nota dan katalog produk & 10 \\
\hline Mendatangi toko & 30 \\
\hline Memberikan nota penjualan & 3 \\
\hline Mengganti produk lama & 5 \\
\hline Melakukan pembayaran produk terjual & 5 \\
\hline Memberikan katalog produk dan nota pesanan & 2 \\
\hline Mencatat pesanan & 3 \\
\hline Menyerahkan katalog produk dan nota pesanan & 2 \\
\hline Menyerahkan rincian pesanan & 2 \\
\hline Memproses pesanan & 5 \\
\hline Pengemasan produk & 360 \\
\hline Mendatangi toko & 30 \\
\hline Mengganti produk lama & 5 \\
\hline Memberikan nota penjualan & 3 \\
\hline Menyerahkan pesanan dan nota pesanan & 5 \\
\hline Melakukan pembayaran produk terjual & 5 \\
\hline Membayar pesanan & 4 \\
\hline Menerima pesanan & 3 \\
\hline Total & 482 \\
\hline
\end{tabular}

Tabel 3.12 Waktu yang digunakan pada proses baru.

\begin{tabular}{|l|l|}
\hline Jenis Layanan & Proses Baru (menit) \\
\hline Memesan produk via chat & 5 \\
\hline Mengirimkan katalog produk via chat & 2 \\
\hline Menyerahkan katalog produk dan nota pesanan & 5 \\
\hline Menyerahkan rincian pesanan & 5 \\
\hline Memproses pesanan & 5 \\
\hline Pengemasan produk & 360 \\
\hline Mendatangi toko & 30 \\
\hline Mengganti produk lama & 5 \\
\hline
\end{tabular}




\begin{tabular}{|l|l|}
\hline Memberikan nota penjualan & 3 \\
\hline Menyerahkan pesanan dan nota pesanan & 5 \\
\hline Melakukan pembayaran produk terjual & 5 \\
\hline Membayar pesanan & 4 \\
\hline Menerima pesanan & 3 \\
\hline Total & 437 \\
\hline
\end{tabular}

\section{Kesimpulan}

Berdasarkan hasil analisis SWOT diperoleh nilai IFAS dan EFAS. Pada IFAS faktor kekuatan bernilai 1,55 dan faktor kelemahan bernilai 1,75. Sedangkan EFAS faktor peluang bernilai 1,7 dan faktor ancaman bernilai 1,45. Selisih pada IFAS dan EFAS berada di posisi kuadran 3 dimana menekankan kelemahan dan menggunakan peluang yang ada di UD. Top Stiker.

Jurnal:

[1] M. Tka and S. Ayachi, "Comparison of Business Process Models as Part of BPR Projects," vol. 5, pp. 427-436, 2012.

[2] N. L. Wisayani, Kertahadi, and Riyadi, "Analisis Business Process Reengineering Untuk Mengevaluasi, Merekayasa Ulang, Dan Memperbaiki Monitoring Kontrak Pada Pt Pln (Persero) Dist. Jatim Area Malang.," J. Adm. Bisnis, vol. Vol.8 No.I, no. 1, pp. 1-10, 2014.

[3] S. E. E. Profile, "Business Process Reengineering ( BPR ) Sistem Penjualan Pada PT Anugrah Pharmindo Lestari Business Process Reengineering ( BPR ) Sistem Penjualan Pada PT Anugrah Pharmindo Lestari," no. February 2016, pp. 0-8, 2018.

[4] D. Kumar and A. Bhatia, "Role of IT in Business Process Reengineering," no. Davenport 1993, pp. 48-51, 2011.

[5] H. Gunawan et al., "Formulasi Strategi Bisnis Pada PT. Duta Waru Kencana dengan Pendekatan SWOT Analysis," vol. 4, no. 1, pp. 213-219, 2016.

[6] Y. Xu, "SWOT Analysis of E-commerce Websites — Based on Dangdang.com," pp. 2016-2018, 2016.

[7] A. Nurlifa, N. Sulistianingsih, and V. M. Haqni, "Rekayasa Ulang Proses Bisnis Administrasi Tugas Akhir dan Wisuda," Semin. Nas. Apl. Teknol. Inf., pp. 11-17, 2013.

[8] D. Wimpertiwi, A. H. Sasongko, and A. Kurniawan, "Konsep Business Process Reengineering Untuk Memperbaiki Kinerja Bisnis Menjadi Lebih Baik: Studi Kasus Perusahaan Susu Kedelai ' XYZ,'” vol. 5, no. 2, pp. 658-668, 2014.

[9] Y. Subaktilah et al., "Analisis SWOT: Faktor Internal dan Eksternal pada Pengembangan Usaha Gula Merah Tebu (Studi Kasus di UKM Bumi Asih, Kabupaten Bondowoso)," vol. 12, no. 02, 2018.

[10] A. S. Saputro and E. Yulianto, "Perencanaan Strategi Pemasaran Paket Data Kampus Dalam Persaingan di Bidang Paket Data Internet (Studi Kasus pada PT. Telkomsel Cabang Malang)," vol. 36, no. 1, pp. 163-169. 